\title{
The Technology of Teacher Reflexive Competence Development in Modern Conditions
}

\author{
Elena E. Merzon ${ }^{1}$, Irina E. Nurgatina ${ }^{1} \&$ Guzaliya M. Bakhayeva ${ }^{2}$ \\ ${ }^{1}$ Kazan (Volga region) Federal University, Kazan, Russia \\ ${ }^{2}$ The University of Management of Tatar Institute of Business Cooperation, Kazan, Russia \\ Correspondence: Elena E. Merzon, Director of Yelabuga Institute of Kazan Federal University, Kremlyovskaya \\ Street 18, Kazan, 420008, Russia. E-mail: emerzon@mail.ru
}

Received: December 29, 2014

Accepted: January 22, 2015 Online Published: February 11, 2015

doi:10.5539/res.v7n4p112

URL: http://dx.doi.org/10.5539/res.v7n4p112

\begin{abstract}
The person-centered, integrative and project approaches form the basis of the presented technology of teacher reflexive competence development in modern conditions. The article reveals the essence and the basic components of the teacher reflexive competence, describes the implementation of an exemplary algorithm of reflexion in practice, marks the teaching strategies of teacher reflexive competence development, proposes the main stages and pedagogical conditions of its development. The article can be useful to students, teachers of high educational institutions and additional vocational education institutions in the process of teacher reflexive competence development in modern conditions.
\end{abstract}

Keywords: reflexion, competence, reflexive competence, technology of teacher reflexive competence development

\section{Introduction}

In modern conditions the assessment of the vocational education effectiveness and professional activities of the personality is carried out from the perspective of the competence-based approach (Baidenko, 2005; Zeer, 2005; Zimnyaya, 2004; Raven, 2002; Tatur, 2004; Khutorsky, 2013). As a part of the competence-based approach, the essence of which is to focus on specialist models that bring together the interests of the individual and society, allows to build a system of advanced broadcast labor market needs and demands of society in the education space, to draw attention to educational outcomes, expressed in terms of competences (Medvedev \& Tatur, 2007), especially relevant today is the problem of development of common cultural and professional competences.

The reflexive competence is becoming particularly relevant among the competences of the modern teacher. The reflexion as one of the most important characteristics of theoretical thinking must be acquired by students. But in order it to be developed the teacher must have reflexion and reflexive activity experience.

Basing on the statements of V. Z. Woolf and V. N. Harkin that professional reflexion contains the unity of human (the ability to self-study, analysis of cause-and-effect links, doubts, implementation of value criteria, work on oneself) and professional, i.e. the use of this ability in difficult conditions and circumstances of the professional life (Woolf \& Harkin, 1995), we focus on the fact that the teacher should have not only a personal reflexion, but a reflexion of professional activities on the taught subject. The personal reflexion is characterized by the processes of self-awareness, self-knowledge, self-esteem, self-control, self-examination. The professional reflexion is characterized by the ability to carry out the analysis of applied technologies, methods, techniques, training methods to improve the quality of education and create conditions for the development of student's personality as well as the ability to carry out the educational process of pedagogical diagnostics and forecasting its development in the nearest and distant future.

\subsection{Literature Review}

Before proceed to creating the technology of teacher reflexive competence there have been studied and analyzed different definition of "reflexive competence", namely:

N. V. Zelenko wrote that "reflexive competence is related to integrative, an inherent ability of the teacher to evaluate his/her work as a whole, the ability to see the cause-and-effect relationship between its goals, objectives, 
methods, means, conditions, results" (Zelenko, 2006).

V. I. Stenkova determined reflexive competence as an adequate concept of one's professional characteristics, the ability to regulate one's professional activities (Stenkova, 2007).

According to U. V. Kusheverskaya, reflexive competence is the system forming component of professional pedagogical activity and the quality of the personality allowing to carry out a reflexion in the most efficient and appropriate way, that provides development and self-development, promotes creativity in educational and professional activities, achievement their maximum effectiveness and efficiency (Kusheverskaya, 2007).

V. A. Metaeva highlights reflexive competence as the acmeological phenomenon that contributes to achievement the best results in the work and she defines it as a metacompetence (Metaeva, 2006).

The research of Davydov (2009), Kunakovskaya (2011), Kusheverskaya (2007), Metaeva (2006), Stetsenko (2006) confirms the position that the process of the reflexive competence development emerges as an important component of life-long teacher education.

\section{Methodological Framework}

The technology of teacher reflexive competence development is based on the following approaches:

1) Person-centered approach, according to which the development of learner's reflexive competence is performed due to its individual characteristics as the subject of knowledge and professional activities, values, research, training and methodic interests, educational needs and experience of pedagogical activity in the process of design and implementation of individual education paths in teacher's professional development.

2) Integrative approach, according to which the development of reflexive competence is implemented in the context of knowledge and action unity in the context of teacher's professional strategy with full immersion and "living" specific professional situations, solving problems based on the integration of knowledge, efficient pedagogical experience and innovative strategies in pedagogical activities.

3) The project approach, according to which the reflexive competence development occurs in a high degree of motivation and emotional intensity, high share of self-learning search and research activities with the prevalence of problematicity in studying during the implementation of innovative practice-oriented projects and interaction of creative problem groups.

\section{Results and Discussions}

The analysis of the works by Kuzmina (1993), Markova (1996), Mitina, (1998), Shadrikov (2006) and the content analysis of competences in the field of training, education and development of student's personality, presented in the Project of professional standard of a teacher (2013), allowed to identify the following core competences, formed and developed in the system of life-long pedagogical education: professional - ethical competence, special competence in a taught subject (subject competence), methodic competence, communicative competence, social competence, informational competence, managerial competence, reflexive competence.

Table 1. Competences of the modern teacher formed and developed in the system of life-long pedagogical education

\begin{tabular}{lll}
\hline No. & Name & Definition \\
\hline 1 & Professional and ethical competence & $\begin{array}{l}\text { The integrative quality of teacher's personality including the } \\
\text { ability and willingness to observe ethical norms and rules of } \\
\text { professional activity. }\end{array}$ \\
2 & Special competence in the taught & The integrative quality of teacher's personality including the
\end{tabular}
subject (subject expertise) knowledge of scientific field basics taught to the students.

3 Methodical competence The integrative quality of teacher's personality including the knowledge and possession of the taught subject methodic, the ability to select and use appropriate to certain objectives technologies, forms, methods and means of teaching.

4 Communicative competence The integrative quality of teacher's personality including the oral and written communication knowledge and skills, the ability to find effective ways of pedagogical interaction which are adequate to specific pedagogical situations, ability to cultural verbal behavior. 
5

Social competence

6

Information competence

7

Managerial competence

8

Reflexive competence

The integrative quality of teacher's personality including the ability to collective professional activities, cooperation, ability to interact with different social institutions, social responsibility for the results of one's professional work.

The integrative quality of teacher's personality including the ability to find, analyze and select relevant information from various sources, save, convert and transfer it independently, the ability to critical perception of information resources containing materials, the ability to use modern information and communication technologies.

The integrative quality of teacher's personality including the ability to set the general and specific objectives of training, education and development of student's personality, to choose appropriate forms, methods and means of their achievement, to carry out planning, modeling, implementation, reflexion and forecasting of pedagogical activities, to make their own effective managerial decisions in professional activities adequate to a specific pedagogical situation.

The integrative quality of teacher's personality including integrative knowledge of the psychological determinants of reflexion, the ability to practice the techniques of its actualization, the ability to analyze one's own teaching activities and the activities of all subjects of the educational process as a whole, the ability to see and explain the cause-and-effect relationships between the various components of pedagogical activity and education process.

Based on the fact that the teacher's reflexive competence appears and is developed only in activities, in the pedagogical interaction and communication, and appears in the organic unity of professional knowledge, special skills and values, we can distinguish the following structure of the reflexive competence:

- Motivational component (the teacher's awareness of pedagogical objectives and tasks as well as the consequences of one's own actions and accepted decisions, the awareness of the need for reflexive activity, the presence of motives and needs in this type of activity);

- Cognitive component (integrative knowledge about the psychological determinants of reflexion and ways of its actualization in practice);

- Values component (the teacher's personal attitude to the content of reflexive activity and its various entities);

- Processual component (the ability to analyze, monitor and adjust their own professional activities in a specific pedagogical context, to compare it with the generally accepted standards and to improve it basing on it and to take the initiative in order to achieve their own progress, the ability to see and explain the cause-and-effect relationships between various components of pedagogical activity and educational process).

An exemplary algorithm of the reflexion's implementation as a phenomenon in the practical work of the teacher can be characterized as follows:

1) Awareness of the need for rapid assessment of specific pedagogical situation, the assessment of your psychological state and evaluation of subjects' reaction to the situation, that arises in the process of pedagogical interaction.

2) The emergence of a teacher's question: What should I do in this situation?

3) The occurrence of a sudden decision or several possible solutions to specific pedagogical situation.

4) Selection of one of the possible solutions to the specific situation of pedagogical interaction.

5) In the event that a specific decision has not yet been found, and there is no more time to think, the teacher uses teaching improvisation, which is intuitive, but its foundations are a high level of formation of teacher's common cultural and professional competences and his professional experience. 
The use of the reflexion in professional activities allows the teacher to ensure the transfer of the experience of practice on the process of development of common cultural and professional competences, provide the necessary level of autonomy, independence, responsibility for the results of professional practice, develop the ability to self-control and self-esteem, as well as provide a dynamic move from incomplete knowledge to a more full understanding of the prospects for personal development of the teacher in his profession.

In the process of development the teacher's reflexive competence we can distinguish the following teaching strategies:

- The use of interactive teaching methods (business and role-playing, group discussions, round table method, the method of analysis of specific practical situations and others),

- Modeling of pedagogical situations,

- Construction of reflexive cases,

- Analysis of typical and atypical problem situations.

\section{The main stages of the development of the teacher's reflexive competence are:}

Stage 1 (motivational stage), in which stable motivation and personal interest of the teacher to implement a reflective activity develops.

Stage 2 (cognitive stage), during which the actualization of integrated knowledge of the psychological determinants of the reflexion and its manifestations in practice are carried out.

Stage 3 (technological stage), in the course of which reflexive and communicative exercises are carried out, teaching situations are modeled, reflective cases are constructed, pedagogical tasks are solved, typical and atypical problem situations are analyzed, interactive teaching methods are used (business and role-playing, group discussions, round table method, the method of analysis of specific practical situations and others).

Stage 4 (practical stage), during which the relationship of educational and practical material with practical activities is implemented adequately specific practical conditions and situations, standard and non-standard professional tasks are developed and a self-realization in the reflective activity takes place.

The following pedagogical conditions make for the effective formation of the teacher's reflective competence:

1) The formation and development of integrated knowledge of the reflexion's psychological determinants, methods of its actualization in practice;

2) Development of the need for introspection, self-knowledge, self-development, self-understanding and others;

3) Development of training and methodic support of the formation of reflective competence (modeling of pedagogical situations, designing reflexive cases, creation of innovative developments, the bank of typical and atypical problem situations, the bank of lessons' video clips and extra-curricular activities, a selection of articles on the current problem of psycho-pedagogical themes for reflective activities, development of special courses for the formation of reflective competence, etc.);

4) The creation of a reflexive environment in the learning process (organization of educational and professional activity in positions of educational process's subjects cooperation that does not require professional knowledge of simple reproduction or copying of formal professional activities, and the learning process is initiated by a joint discussion of important for practice teaching professional problems and possible ways and means of its decision in the context of a specific pedagogical situation and the conditions in which it has been originated);

5) Development of personal reflexive experience in professional activities;

6) Designing and implementation of individual education paths of teacher's professional development, consulting and tutorial support of this process;

7) Implementation of pedagogical monitoring of the reflexive competence's development process.

\section{Conclusion}

Thus, the importance of the problem of the teacher's reflexive competence development is connected with the importance of reflexive component in the educational activity, which allows the teacher to find his own individual learning style, to achieve adequate professional and personal self-esteem, to predict, to analyze, and take responsibility for the results of their work.

The result of the teacher's reflexive activity is the development and self-development of the teacher. 


\section{Acknowledgments}

The work is performed according to the Russian Government Program of Competitive Growth of Kazan Federal University.

\section{References}

Baidenko, V. I. (2005). Competence-based approach to the design of the state educational standards of higher professional education (methodological and methodical questions) (p. 114). Moscow: Research Center of Problems the quality of specialists training.

Davydov, G. I. (2009). Reflective dialogue in the educational process of the university. Author's abstract of Dissertations of the doctor of pedagogical sciences (p. 44). Moscow.

Khutorsky, A. V. (2013). Competence-based approach in teaching (p. 73). Moscow: Eidos.

Kunakovskaya, L. A. (2011). Reflexive culture of the teacher (p. 64). Voronezh: Voronezh State University.

Kusheverskaya, U. V. (2007). Formation of reflective competence of students in the educational process of pedagogical college (p. 21). (Author's abstract of Dissertations of candidate of pedagogical sciences). Petrozavodsk.

Kuzmina, N. V. (1993). Professionalism of teaching (p. 202). St. Petersburg: Leningrad State Pedagogical University.

Markova, A. K. (1996). Psychology of professionalism (p. 308). Moscow.

Medvedev, V., \& Tatur, U. (2007). Preparing high school teacher: competence-based approach. Higher education in Russia, 1, 46-56.

Metaeva, V. A. (2006). Reflection as metacompetence. Pedagogy, 3, 57-61.

Mitina, L. M. (1998). Psychology of professional development of teachers (p. 115). Moscow: Moscow Psychological and Social Institute.

Professional standard of a teacher (project). (2013). http://минобрнауки.рф/документы/3071

Raven, J. (2002). Competence in modern society: The identification, development and implementation (Trans. from English) (p. 396). Moscow: Cogito Center.

Shadrikov, V. D. (2006). Personal qualities of the teacher as components of professional competence. Bulletin of the Yaroslavl State University, 1, 15-20.

Stenkova, V. I. (2007). Pedagogical practice as a factor in the development of professional competence of future psychologists, teachers of psychology: Dissertation of the candidate of pedagogical sciences (p. 23). Ulan-Ude: Buryat State University.

Stetsenko, I. A. (2006). Theory and practice of teaching students of reflection (p. 256). Rostov-on-Don: Rostov State University.

Tatur, Y. G. (2004). Competence-based approach in the description of the results and the design standards of higher education (p. 176). Moscow.

Woolf, V. Z., \& Harkin, V. N. (1995). Pedagogy reflection (p. 175).

Zeer, E. F., Pavlova, A. M., \& Symanyuk, E. E. (2005). Modernization of vocational education: competence-based approach (p. 165). Moscow: Moscow Psychological and Social Institute.

Zelenko, N. V. (2006). The relationship of design and self-design methodical competences in the general technical and methodical preparation of the teacher of technology (p. 38). Author's abstract of Dissertations of the doctor of pedagogical sciences. Armavir.

Zimnyaya, I. A. (2004). Key competences as effectively-Targeted competency-based approach to education ( $\mathrm{p}$. 40). Moscow: Research Center of Problems the quality of specialists training.

\section{Copyrights}

Copyright for this article is retained by the author(s), with first publication rights granted to the journal. This is an open-access article distributed under the terms and conditions of the Creative Commons Attribution license (http://creativecommons.org/licenses/by/3.0/). 